DOI: https://doi.org/10.32838/2523-4803/69-4-5

УДК $330.322+330.341 .1$

\title{
Гаман М.В.
}

доктор наук з державного управління, професор, професор кафедри економічної політики та врядування,

Національна академія державного управління при Президентові України

Жук В.П.

кандидат наук $з$ державного управління, доцент, доцент кафедри економіки, підприємництва та природничих наук

Таврійський національний університет імені В.І. Вернадського

\section{Gaman Mykola}

National Academy of Public Administration under the President of Ukraine

Zhuk Viktoriia

Taurida National V.I. Vernadsky University

\section{СИСТЕМА ФОРМУВАННЯ ІННОВАЦИЙО-ІНФОРМАЦЙНОЇ ІНФРАСТРУКТУРИ РЕГІОНУ}

\begin{abstract}
Визначено, щзо процеси децеентралізації в Україні привели до того, щзо регіони здійснюють велику кількість різноманітних функиій державного управління і регулювання, мають у своєму розпорядженні значні матеріальні, трудові та фінансові ресурси. Зазначено, щзо регіональні $і$ центральні органи влади Украӥни прагнуть мати більш чітке уявлення про характер і тенденції розвитку кожного регіону, про його виробничий потенціал, про обсяг і структуру випуску товарів $і$ послуг, про його матеріальні, фінансові і трудові ресурси, про рівень життя населення тощо. Це необхідно для вироблення і реалізації ефективної соціально-економічної політики иеентру стосовно регіонів. Облік цุих процесів необхідний для міжрегіональних зіставлень, об'єктивної оцінки процесу реалізації економічних реформ на місиях, визначення частки цього округу або регіону в доходах і витратах краӥни, для встановлення «ціни» його участі в міжрегіональної інтеграції. Особливу важливість у изих умовах має прийняття максимально виважених управлінських рішень.
\end{abstract}

Ключові слова: інновачійно-інформаційна інфраструктура, регіон, система, формування.

Постановка проблеми. У сучасному світі управління розвитком регіону на основі статистичної, інформаційно-аналітичної системи і державне регулювання їх використання стали загальновизнаними і необхідними елементами економічної діяльності та стратегічного планування. Пошук оптимальних рішень безлічі питань, що виникають, зумовлює необхідність всебічного дослідження відносин, що складаються між державою і іiі регіонами, державою і бізнесом, державою і населенням, роботодавцями та найманими працівниками, державними установами та окремими підприємцями, а також розроблення конкретних практичних рекомендацій щодо формування ефективного механізму управління розвитком регіону на основі статистичної, інформаційно-аналітичної системи.

Аналіз останніх досліджень і публікацій. Дослідження щодо розбудови інформаційного суспільства в Україні, інформаційного забезпечення органів державної влади згідно з концепцією електронного урядування здійснювалися такими науковцями: О. Бакаєвим, Я. Берсуцьким, А. Берсуцьким, В. Глушковим, Р. Калюжним, В. Корогодіним, М. Лепою, В. Порохнею, С. Романенком, В. Ситником, В. Шамраєм та ін.
Науковими дослідженнями регіональної статистичної інформаційно-аналітичної системи, у тому числі на державному та регіональному рівнях, займалися такі вітчизняні вчені, як: Н. Бусленко, С. Балашов, В. Гончаров, В. Глушков, Н. Дацій, Я. Жовнірчик, А. Іваненко, Н. Міхеєва, І. Кононенко, М. Раду, Г. Поспєлов, Ю. Якутін та ін.

Проте можна стверджувати, що це питання вимагає додаткових наукових досліджень, що і зумовило вибір теми статті.

Постановка завдання. Метою статті $є$ дослідження підходів до формування інноваційно-інформаційної інфраструктури регіону.

Виклад основного матеріалу дослідження. Будьякий регіон, будучи складною соціально-економічною системою, має багатоцільову спрямованість розвитку. Траєкторія і швидкість руху його економіки залежать від конкретних умов: екологічної ситуації, геополітичної і демографічної обстановки, рівня зайнятості тощо. Ці умови, своєю чергою, залежать від природно-ресурсного потенціалу, галузевої структури господарства, економіко-географічного положення, розвиненості інфраструктури, етнічного 
складу населення. Автори у своєму дослідженні пропонують під регіоном розуміти відокремлену частину народного господарства країни, в якій здійснюється повний (закінчений) цикл суспільного виробництва за фазами, факторами виробництва і результатами [1].

Вивчення господарства регіонів в Україні велося століттями, але епоха конструктивних досліджень 3 активним цілеспрямованим перетворенням економіки територій почалася в радянські часи. 3 нею пов'язано зародження і становлення регіональної економіки як наукового напряму.

Змінюється економічний потенціал, змінюється політика держави, і разом з ними змінюються методологія, форми, методи управління розвитком регіонів. Велике значення отримав новий для регіональної економіки фінансовий аспект територіального розвитку. Можна розглядати регіон як квазідержаву, в цій якості регіон являє собою відносно відокремлену підсистему держави і національної економіки.

Процеси децентралізації в Україні привели до того, що регіони здійснюють велику кількість різноманітних функцій державного управління і регулювання, мають у своєму розпорядженні значні матеріальні, трудові і фінансові ресурси. В країні є значна диференціація рівнів економічного і соціального розвитку регіонів, а отже, і регіональних округів. Тому не тільки територіальні органи управління, але і держава зацікавлена в статистичній інформації, що комплексно характеризує регіональну економіку і дає змогу здійснювати вироблення економічної політики й оцінку ефективності прийнятих управлінських рішень як на регіональному рівні, так і на рівні держави.

У цих умовах регіональні і центральні органи влади України прагнуть мати більш чітке уявлення про характер і тенденції розвитку кожного регіону, про його виробничий потенціал, про обсяг і структуру випуску товарів і послуг, про його матеріальні, фінансові і трудові ресурси, про рівень життя населення тощо. Це необхідно для вироблення і реалізації ефективної соціально-економічної політики центру стосовно регіонів. Облік цих процесів необхідний для міжрегіональних зіставлень, об'єктивної оцінки процесу реалізації економічних реформ на місцях, визначення частки цього округу або регіону в доходах $\mathrm{i}$ витратах країни, для встановлення «ціни» його участі в міжрегіональній інтеграції.

Системна робота зі статистичною інформацією передбачає використання наукових процедур і правил відбору, аналізу й оцінки результатів. Тому актуальна «думка про корисність і важливість системного підходу до вирішення проблем», який забезпечить узгоджене пізнання багатьох явищ і процесів, їх класифікацію, дасть змогу виявити об'єктивні закономірності.

Концепція впровадження систем або «системного підходу» орієнтована на досягнення конкретних цілей. Ключовими питаннями фази діагностики є: «Де ми знаходимося зараз?», «Де ми хочемо бути?», «Як ми дізнаємося, що потрапили туди, куди треба?».
Фаза проектування вирішує проблеми: «Як ми потрапимо туди, куди треба?». Фаза введення в дію вирішує проблеми: «Які потрібні кроки, щоб потрапити туди, куди треба?».

Помітним трендом останнього часу в методології системного підходу є підвищення глибини перекриття цих блоків і «стягування» їх до спільного центру - цілі.

Це проявляється в скороченні часу, який виділяється на проведення формального аналізу, що охоплює не такі далекі тимчасові горизонти, скорочення часу для реалізації змін, збільшення числа необхідних змін, запланованих одночасно.

Якщо застосувати описану систему до системи виконавчої влади, то побачимо, що спотворює вплив мінімум двох факторів. Перший 3 них - це неминуче існування тих, за ким завжди залишається останнє слово у відповіді на питання: «Що є істина?». Це - влада приймати економічні рішення. Другий фактор - якість статистичної інформації, на основі якої приймаються управлінські рішення. «Хибність, що не зводиться до статистичних даних, які публікуються, була, є i, напевно, буде «притчею економічними мовами», - пише О. Карпенко. Далі він продовжує свою думку: «Обмежуся зауваженням про те, що, по суті, всі соціально-економічні показники, що нині збираються і публікуються, не характеризують справжнього стану справ в країні [2, с. 24].

Доти, доки не переосмислена процедура економічних вимірювань, поки не будуть гранично жорстко застосовуватися чинні стандарти статистичного рахунку і нові стандарти у галузі статистичних вимірювань, економічні оцінки як потужне знаряддя не тільки пізнання, а й перетворення дійсності, як і раніше, будуть кульгати».

Те, що інформація є недосконалою, чітко розуміють всі економісти. Може, вони сподівалися, що поведінка економік із недосконалою інформацією багато в чому схожа $з$ поведінкою економік із досконалою інформацією. Іноді можна знайти методи, що дають змогу досягти повного розкриття інформації, і проблема інформації виявляється повністю вирішеною. У реальному світі такого, зрозуміло, ніколи не відбувається.

Ефективний перерозподіл прав і повноважень між центром і регіонами - процес життєво необхідний у період становлення ринкових відносин i, на жаль, тривалий. Відсутність чіткого розмежування функцій центру і регіонів гальмує вироблення механізмів їхньої економічної взаємодії. У зв'язку з цим удосконалення управління і реалізація економічних реформ передбачає здійснення проекту інформатизації соціального і економічного розвитку на регіональному рівні. Прийняття виважених рішень органами виконавчої влади регіону має грунтуватися на базі статистичних даних. Особливістю проектів цього напряму є складність їх реалізації, пов'язана, по-перше, з великим обсягом статистичної інформації, що надходить від значної кількості джерел, по-друге, з підвищеними 
вимогами до оперативності, достовірності, актуальності та способів надання інформації користувачам.

Нові інформаційні проблеми породжує реалізація принципу децентралізації і становлення місцевого самоврядування. Адже за всієї самостійності державних органів регіонів і органів місцевого самоврядування всі вони функціонують у єдиному інформаційному просторі і повинні знати про те, що і як роблять інші. Виконання цих вимог можливе за рахунок інтеграції наявних і створюваних інформаційних систем центрального, обласного та місцевого рівнів, на основі регіональної статистичної інформаційноаналітичної системи, що використовується для узагальнення, аналізу та надання статистичної й аналітичної інформації користувачам із застосуванням IКТ. Насамперед інформатизації підлягають основні сфери функціональної діяльності регіональних органів державної влади (виробництво, економіка, фінанси, соціальна сфера та ін.).

Особливу важливість у цих умовах набуває прийняття максимально виважених управлінських рішень, основою для розроблення яких є повна, об'єктивна й актуальна в тимчасовому аспекті статистична інформація, яка висвітлює всі процеси і явища, які підлягають регулюванню. Чітко сформулювати завдання і цілі можна лише в тому разі, якщо апарати органів виконавчої і законодавчої влади володіють всією сукупністю інформації, що забезпечує глибокий комплексний аналіз соціально-економічної ситуації території.

Соціально-економічні завдання регіональної політики нині не можуть бути вирішені без інформаційного забезпечення із застосуванням сучасних інформаційних технологій. Для вирішення складних завдань економічної та соціальної політики необхідне застосування конкретних методів та механізмів державного регулювання економіки регіонів. Це вимагає проведення ефективного моніторингу результатів прийнятих управлінських рішень, що, в свою чергу, висуває жорсткі вимоги до якості інформаційного забезпечення органів влади.

Водночас в Україні на регіональному рівні поки немає типової спеціально організованої системи, яка б оперативно відображала різні аспекти і тенденції регіонального розвитку. Інформаційні ресурси державної статистики в регіонах надають набір в основному макроекономічних показників, які найбільш підходять для вирішення завдань економічного регулювання й управління країною загалом.

Така система являє собою сукупність статистичних інформаційних ресурсів, інформаційно-комунікаційних технологій, аналітичних функцій, що забезпечують:

- упорядкованість статистичних інформаційних ресурсів з урахуванням наявної сучасної системи наукових поглядів;

- зберігання та інтеграцію статистичної інформації в базах даних за всіма основними показниками господарюючих суб'єктів;
- перетворення даних у вигляді ієрархії агрегації (наприклад: область - район - місто - поселення);

- зберігання тимчасової ознаки в даних, що дає можливість відстежувати динаміку зміни показників протягом тривалого періоду часу (наприклад: рік квартал - місяць);

- актуалізацію даних, несуперечливість даних у всіх використовуваних джерелах протягом певного часу;

- можливість відбору показників за предметно і проблемно-орієнтованою ознакою;

- опис досліджуваних регіональних ситуацій i проблем у системі характерних для них ознак (параметрів, показників);

- кількісну і якісну оцінку цих ситуацій і проблем.

Система регіональної статистичної інформації нині базується на сукупності показників державних статистичних спостережень. Потреба регіону в тій чи іншій статистичної інформації залежить від географічних, історичних, соціально-економічних особливостей регіону, чинної системи управління та повноважень органів управління, чинних правових i нормативних актів.

Принципами побудови i функціонування регіональної інформаційної системи є:

- застосування єдиних вимог до технічних і програмних засобів;

- забезпечення технологічної можливості інформаційної взаємодії раніше створених і новостворюваної інформаційних систем органів влади та статистики;

- відповідальність органа статистики за повноту, достовірність статистичних інформаційних ресурсів, їх своєчасну актуалізацію і зберігання в установленому порядку;

- мінімізація витрат, в тому числі фінансових і тимчасових, під час отримання адміністративних інформаційно-статистичних послуг в електронному вигляді;

- забезпечення регламентованого доступу в процесі надання адміністративних інформаційних послуг;

- використання органами влади програмної інфраструктури інформаційної системи;

- забезпечення захисту інформації здійснюється відповідно до законодавства України.

Формування інформаційних ресурсів Державної служби статистики України на всіх його рівнях здійснюється на метаінформаційній сукупності методологічних матеріалів Державної служби статистики України, що містить загальні положення про систему економічних класифікацій, що застосовуються в статистиці; офіційну методологію обчислення статистичних показників; методи збору i формування статистичної інформації. Методологічні матеріали використовуються під час вирішення різних статистичних завдань, а також для інформаційно-довідкового обслуговування користувачів статистичної інформації.

Електронний каталог статистичних показників (далі ЕКСПО) - це інформаційно-довідкова система метаінформації. 3 погляду економічного змісту, це 
систематизований перелік показників, які використовуються в статистичній практиці. 3 погляду організації даних він $є$ взаємопов'язаною сукупністю показників, нормативно-довідкової інформації, таблиць метаданих, розміщених на сервері Державної служби статистики України. Каталог (ЕКСПО) має централізований доступ користувачів за допомогою прикладного програмного забезпечення. Статистичні показники в ЕКСПО характеризують кількісну і якісну сторони соціально-економічних процесів у суспільстві, що відображають сутність явища або процесу із зазначенням конкретних умов місця і часу.

Інформаційне сховище (далі IC) являє собою базу узагальненої інформації, що формується 3 безлічі зовнішніх і внутрішніх джерел, на основі якої виконуються статистичні угруповання та інтелектуальний аналіз. Порівняно з базами даних оперативної обробки транзакцій IC забезпечує більш гнучке і просте формування довільних довідкових та аналітичних запитів, а також застосування спеціалізованих методів статистичного та інтелектуального аналізу даних.

Внаслідок передачі державою окремих функцій регіону, національного центру все менше і менше потрібна детальна статистична інформація про регіони, звідси відбувається скорочення показників i форм статистичного спостереження, що затверджуються на регіональному рівні.

Для потреб регіонів, навпаки, необхідно розширити систему показників і зробити більш докладними форми статистичного спостереження. Проводячи доопрацювання статистичної інформаційної бази в регіоні, слід врахувати той факт, що вона повинна спиратися на інформаційну інфраструктуру Державної служби статистики України. Це дає реальну можливість впоратися із завданням інформаційного забезпечення процесів управління в регіоні та забезпечити єдину методологію (використання класифікаторів, стандартів, методики розрахунків та ін.) збору, обробки, зберігання інформації.

На жаль, часто статистична інформація залишається незатребуваною на регіональному рівні через такі причини.

Суб'єктивна. Для сприйняття статистичної інформації необхідні спеціальні знання, якими деякі керівники не володіють, і тому з'являється недовіра до статистичної інформації.

Об'єктивна. Сьогоднішня система збору та обробки інформації мало пристосована до використання на рівні регіону.

Виникає парадокс: доки не вирішена перша проблема - проблема професійної підготовки керівника, немає потреби в статистичній інформації. А не буде вирішена друга - проблема створення інформаційних ресурсів, необхідних для прийняття управлінських рішень, відпаде потреба в професійному використанні інформаційних даних.

Тому створення єдиної регіональної інформаційної системи дасть змогу вирішити зазначені проб- леми за рахунок надання таких нових можливостей керівникам і фахівцям регіональних органів влади й управління:

- отримувати статистичні дані соціально-економічного становища території на місцевому, регіональному, міжрегіональному та національному рівнях;

- здійснювати пошук, отримання, передачу i поширення статистичної інформації з баз даних такої системи із застосуванням новітніх інформаційних технологій;

- використовувати інформаційні ресурси на базі єдиного ЕКСПО з метою найбільш ефективного вирішення основних завдань управління і прогнозування в усіх сферах, включаючи аналіз стану і динаміки розвитку регіональної економіки, підвищення інвестиційної активності й ефективності фінансової системи, поліпшення демографічної і соціальної ситуації;

- проводити комплексний аналіз сукупності соціальних, економічних, екологічних процесів, що відбуваються в регіоні і в його місцевих утвореннях iз метою прийняття органами влади своєчасних i обгрунтованих управлінських рішень;

- забезпечувати однакову доступність суб'єктів інформаційної взаємодії до відкритих інформаційних ресурсів і їхню правову рівність;

- підвищувати оперативність і якість прийняття управлінських рішень на стадії експлуатації за рахунок постійної готовності системи адекватно відображати стан об'єктів управління та своєчасно виявляти тенденції в їхньому розвитку;

- застосовувати систему спеціального доступу до інформації обмеженого використання, поширюваної за згодою учасників конкретного інформаційного обміну.

Висновки. Таким чином, у дослідженні розкрито, що еволюція способів формування і надання користувачам статистичної інформації безпосередньо пов'язана 3 політичними, економічними і науковотехнічними перетвореннями держави і потребами державного управління. Процеси децентралізації в Україні привели до того, що регіони здійснюють різноманітні функції державного управління, мають значні матеріальні, трудові і фінансові ресурси. Ефективним інструментом інформаційного забезпечення органів влади й управління регіонів України повинна стати система, яка акумулює й ефективно обробляє великі обсяги статистичної інформації. Удосконалення управління соціально-економічним розвитком регіону на основі єдиної регіональної інноваційноінформаційної системи спрямоване на: підвищення ефективності державного управління; надання повної, достовірної, оптимальної за часом статистичної інформації з метою управління та прогнозування соціально-економічного розвитку регіону; уніфікацію процесів надання інформаційних послуг із застосуванням IКT; створення системи зворотного зв'язку зі споживачами інформаційних послуг; усунення дублювання інформації. 
Список літератури:

1. Дацій O.I., Туболець I.I., Шевченко Н.I. Інформаційний механізм реалізації державної податкової політики на територіальному рівні. Державне управління: удосконалення та розвиток. 2019. № 3. URL: http://www.dy.nayka.com.ua/ ?op=1\&z=1442 (дата звернення: 15.08.2019).

2. Карпенко О. Особливості нормативно-правового визначення інформаційних послуг законодавчими актами країн СНД. Вісник Книжкової палати. 2012. № 6. С. 22-26.

\title{
References:
}

1. Datsii O.I., Tubolets I.I., Shevchenko N.I. (2019). Informatsiinyi mekhanizm realizatsii derzhavnoi podatkovoi polityky na terytorialnomu rivni [Information mechanism for the implementation of the state tax policy at the territorial level]. Derzhavne upravlinnia udoskonalennia ta rozvytok [Public Administration: Improvement and Development], (electronic journal), vol. 3. Available at: http://www.dy.nayka.com.ua/?op=1\&z=1442 (accessed 15.08.2019).

2. Karpenko O. (2012). Osoblyvosti normatyvno-pravovoho vyznachennia informatsiinykh posluh zakonodavchymy aktamy krain SND [Features of the legal definition of information services by legislative acts of the CIS countries]. Visnyk Knyzhkovoi Palaty, vol. 6, pp. 22-26.

\section{СИСТЕМА ФОРМИРОВАНИЯ ИННОВАЦИОННО-ИНФОРМАЦИОННОЙ ИНФРАСТРУКТУРЫ РЕГИОНА}

\begin{abstract}
Определено, что процессы децентрализачии в Украине привели к тому, что регионы осуществляют большое количество разнообразных функиий государственного управления и регулирования, располагают значительными материальнылии, трудовыми и финансовыми ресурсами. Отмечено, что региональные и иентральные органы власти Украины стремятся иметь более четкое представление о характере и тенденциях развития каждого региона, о его производственном потенииале, об объеме и структуре выпуска товаров и услуг, о его материальных, финансовых и трудовых ресурсах, об уровне жизни населения и тому подобное. Это необходимо для выработки и реализации эффективной социально-экономической политики ичентра в отношении регионов. Учет этих прочессов необходим для межрегиональных сопоставлений, объективной оценки хода реализации экономических реформ на местах, определение доли данного округа или региона в доходах и расходах страны, для установления «ценьл» их участия в межрегиональной интеграции. Особую важность в этих условиях приобретает принятие максимально взвешенньх управленческих решений.

Ключевые слова: инновационно-информационная инфраструктура, регион, система, формирование.
\end{abstract}

\section{SYSTEM OF FORMATION OF INNOVATION-INFORMATION INFRASTRUCTURE OF THE REGION}

It is determined that the processes of decentralization in Ukraine have led to the regions exercising a large number of various functions of state administration and regulation, having considerable material, labor and financial resources at their disposal. There is considerable differentiation in the levels of economic and social development of regions and, consequently, of regional districts. Therefore, not only territorial authorities, but also the state is interested in statistical information, comprehensively characterizing the regional economy and allowing to make economic policies and evaluate the effectiveness of administrative decisions taken, both at the regional and state levels. Under these conditions, regional and central authorities of Ukraine seek to have a clearer idea of the nature and tendencies of development of each region, its production potential, the volume and structure of output of goods and services, its material, financial and labor resources, and the level of life of the population, etc. This is necessary in order to develop and implement an effective socio-economic policy of the Center towards the regions. Accounting for these processes is necessary for cross-regional comparisons, an objective assessment of the progress of economic reforms on the ground, determining the share of a given district or region in the country's revenues and expenditures, to establish the "price" of its participation in interregional integration. Particularly important in these circumstances is the adoption of the most prudent management decisions, the basis for the development of which is complete, objective and timely statistical information that covers all the processes and phenomena that are subject to regulation. The tasks and goals can be clearly stated only if the executive and legislative bodies possess all the information, which provides a deep comprehensive analysis of the socioeconomic situation of the territory. The study reveals that the evolution of ways of generating and providing users with statistical information is directly related to political, economic and scientific and technical transformations of the state and the needs of public administration. Decentralization processes in Ukraine have led the regions to perform various functions of government. have significant material, labor and financial resources. An effective tool for information support to the authorities and administrations of the regions of Ukraine should be a system that collects and efficiently processes large amounts of statistical information. Improving the management of the socio-economic development of the region on the basis of a single regional innovation and information system aims at: improving the efficiency of public administration; providing complete, reliable, time-optimal statistical information for the purpose of managing and forecasting the socio-economic development of the region; creating a feedback system with consumers of information services; eliminate duplication of information.

Key words: innovation-information infrastructure, region, system, formation. 